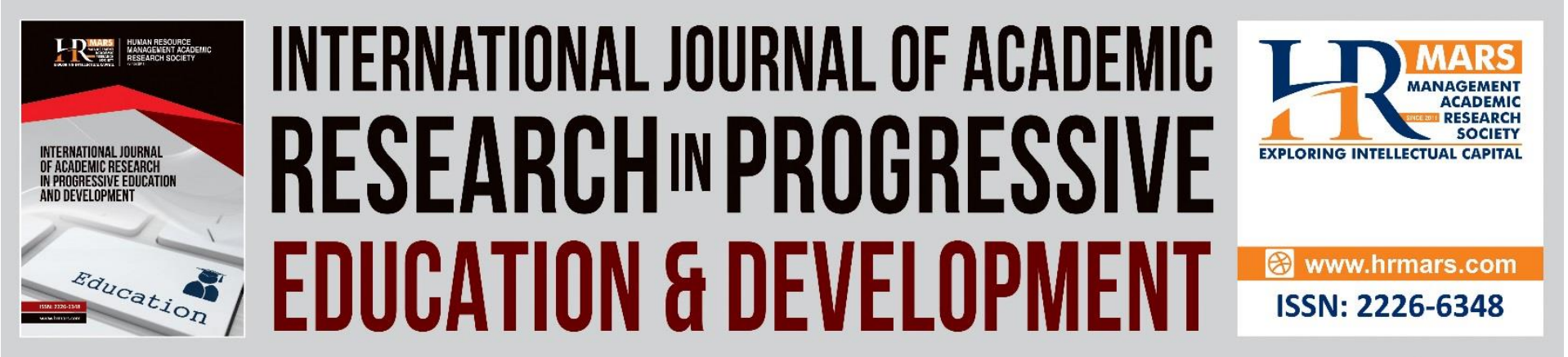

\title{
Factors Enhancing the Establishment of Early Childhood Development Centres in Kakamega Municipality, Kenya
}

Florah K. Burudi, Moses W. Poipoi

To Link this Article: http://dx.doi.org/10.6007/IJARPED/v1-i4/12016

DOI: $10.6007 /$ IJARPED/v1-i4/12016

Received: 18 September 2012, Revised: 22 October 2012, Accepted: 30 October 2012

Published Online: 14 November 2012

In-Text Citation: (Burudi \& Poipoi, 2012)

To Cite this Article: Burudi, F. K., \& Poipoi, M. W. (2012). Factors Enhancing the Establishment of Early Childhood Development Centres in Kakamega Municipality, Kenya. International Journal of Academic Research in Progressive Education and Development, 1(4), 256-264.

Copyright: (c) 2012 The Author(s)

Published by Human Resource Management Academic Research Society (www.hrmars.com)

This article is published under the Creative Commons Attribution (CC BY 4.0) license. Anyone may reproduce, distribute, translate and create derivative works of this article (for both commercial and non-commercial purposes), subject to full attribution to the original publication and authors. The full terms of this license may be seen

at: http://creativecommons.org/licences/by/4.0/legalcode

Vol. 1(4) 2012, Pg. 256 - 264

http://hrmars.com/index.php/pages/detail/IJARPED

JOURNAL HOMEPAGE

Full Terms \& Conditions of access and use can be found at http://hrmars.com/index.php/pages/detail/publication-ethics 


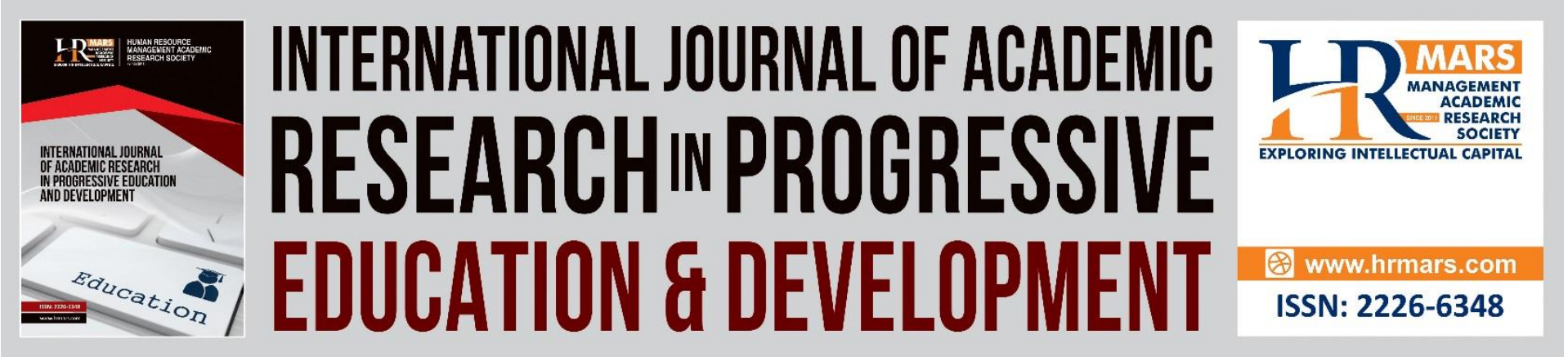

\title{
Factors Enhancing the Establishment of Early Childhood Development Centres in Kakamega Municipality, Kenya
}

\author{
Florah K. Burudi \\ Masinde Muliro University of Science and Technology, P.O Box 190-50100 Kakamega \\ Email: Burudiflora@Yahoo.Com \\ Dr. Moses W. Poipoi \\ Masinde Muliro University of Science and Technology, P.O Box 190-50100 Kakamega \\ Email: Wesangulamp@Yahoo.Com
}

\begin{abstract}
The purpose of this study was to investigate factors enhancing the establishment of ECD centres in Kakamega municipality. The study was guided by a descriptive survey design and data was collected using questionnaires, interview and observation schedules. Kakamega Municipality was chosen as the area of study. Purposive and random sampling techniques were used to sample 60 teachers 10 proprietors, 60 parents, 10 education officers and 10 faith based organizations. The data was analyzed using descriptive statistics such as, frequency counts, means and percentages. The study revealed that establishment of ECD centres is encouraged by; accessibility of children, parents' affordability to pay school dues, parents' busy schedules, enlightenment on the need for children to attend ECDE, pressure from parents and encouragement by the government. It therefore recommended that, the government should provide a specific policy framework within which the ECD centres should be established.
\end{abstract}

Keywords: Developmental Milestones, Early Childhood Development Centres, Establishment, Factors Affecting.

\section{Introduction}

Globally, no country has developed without education. UNESCO International Standard Classification of education defines education as comprising organized and sustained communication designed to bring about learning (Thompson, 1987). Education is therefore meant to bring up from childhood so as to form habits, manners, intellectual and physical aptitudes (Wilson, 2000). Early childhood development education has its foundation in the ideas of renowned authorities in early childhood education, Froebel and Montessori. According to the two scholars, early childhood education is provided to children aged three to six years. Its purpose is to prepare the young children for formal schooling by helping them learn being away from their home environment, train them to socialize or interact with other children or strangers in a school setting and instill in them desirable habits (Chaube \& Chaube, 
2003). Eileen and Betty (1984) concur that, individual social and emotional adjustment and personal fulfillment in adulthood is linked to learning in early childhood education.

According to Eshiwani (1993), education is one of the most important social institutions in the modern society. It has the function of transmitting skills, knowledge, norms, values and practical skills from generation to generation. Education aims at socializing individuals to fit in the society, to function adequately within it when they become adults. From 1963 when Kenya attained independence, successive administrations have continued to emphasize on education as a vehicle for human resources and national development. Indeed, it is now acknowledged that education plays a key role in the development of human capital, which is in turn considered as the most important input in production.

An early childhood development education centre is any place where total needs of children from 1 to 6 years are taken care of. These include; care, love, education, socialization, health and nutrition. The main goal of early childhood development centres is to support the family in childcare and development (Kenya Institute of education, 1999). The early childhood development centres should cater for total needs of children namely; social, emotional, physical, spiritual and mental needs (K. I. E., 1999). The ministry of education has adopted the policy of partnership which allows the participation of various partners in the establishment, financing and management of pre- schools (Republic of Kenya, 2006). Such partners include parents associations, local authorities, religious organizations, welfare organizations, private firms and individuals. It encourages the establishment of pre-school units within primary schools. This is done with a view of creating stronger ties between the two schools and ensures closer supervision and continuity.

The establishment of pre-primary education in Kenya has been as a result of an inter play of factors. The first known pre-school in Kenya was established among the white community in 1942 (Ministry of Education, 1987). This was followed by the establishment of pre-schools among the Asian community and later for the indigenous Africans. The first early childhood education centres for Africans were started in the 1950s (Kabiru, 1993), with custodial care and security of young children being the main factors of concern, with educational component being least pronounced, other authors concur with this view. Nyonyintono (1980) writes that, pre-schools were patterned on racial lines and the main concern being the welfare of the children with a few of them introducing education as part of their activities. Similar views were shared by Sifuna and Karugu (1988). Who argued that, in some districts, nursery schools were started as nutrition centres where children could sing, listen to stories and play organized games, while milk or soup was prepared.

The growth of pre-schools especially in rural Kenya is a community affair. Usually a group of individuals get together and decide to establish a pre-school in their village. The Kenya government made initial direct involvement in early childhood education in early 1960s when the then ministries were charged with the responsibility of inspecting pre-schools to ensure by 1966, the ministry of Housing and social services (later known as culture and social services) started organizing courses for pre-school teachers. There was no national curricular and therefore, each individual pre-school had its own curriculum which was mainly determined by the social status of the school (Sifuna and Karugu, 1988). Institutions that catered for children from upper and middle classes of the society emphasized academic 
education modeled on foreign education systems. The majority of pre-schools catering for children from the lower classes of the society offered non-academic curricular, a lot of the time was spent on singing and there was little variation in activities offered to the children (Kabiru, 1993). In 1970, the ministry of education became directly involved in pre-school education, jointly with the Bernard Leer Foundation. A pre-school education project was started at the Kenya Institute of education (K.I.E). The main objective of the project was to formulate an interventional pre-school education in Kenya.

A report of the National committee on educational objectives and policies (Gachathi Report, 1976), recommended that the K. I. E. should produce a curriculum and culturally relevant materials to be used in Kenya pre-primary school. In 1984, the ministry of Education introduced in service training model through the National centre for early childhood education (NACECE) and a network of sub centres were established at district level, the district Centres for early childhood education (DICECE), starting in 1985. This measure was aimed at addressing the human resource quality in pre-school programmes.

The safety of children is very important if children have to learn and develop. The learning environment must be carefully planned and adequately equipped. The facilities must be organized in a way that they are interesting to meet children's needs such as emotional, social, moral, physical, intellectual stimulation and safety. The centres must meet the basic space and hygienic standards for the comfort and development of young children (K. I. E., 1999). A part from involvement of all training of all levels of staff, sustaining quality improvement also demands the utilization of research. Fortunately, Kenya has a relatively strong tradition of research which has been carried out in the universities and other research institutions. However, the mechanisms for its utilization are either ineffective or non-existent. These mechanisms, therefore, need to be made effective and /or set up. They are required for collecting, collating, storing, analyzing, synthesizing, popularizing and applying the knowledge generated through research.

In Kenya, early childhood development education is geared towards development of the child's mental capabilities and physical growth, learning through play, developing and appreciating his or her culture and environment, fostering the child's exploration skills, creativity, self-expression and discovery, build good habits and acquire acceptable values and behaviours, foster spiritual and moral growth, improve the status of the child's health and nutritional needs, enrich the child's experiences and develop the child's aesthetic and artistic skills (K. I. E., 1999). The learning environment must be carefully planned and adequately equipped to meet children's needs such as emotional, social, physical, and intellectual stimulation as well as basic space for play and hygienic standards for the comfort of young children (Republic of Kenya, 2006). Basing on these objectives of ECE, there is need to find out the extent to which they have been achieved.

Although a school is supposed to be an enjoyable endeavor to a child where play takes much of his or her time, it is evident in Kakamega Municipality that many early childhood Education centres have emerged in locations that are in fact detrimental to the mental, physical, moral, social and psychological health of the child. Some have been set up behind shops, upstairs of storey business premises and some in congested town slums such as Amalemba, Shirere, Kambi-Somali and other residential areas. However, despite this increase, little has been done 
to analyze the impact of these centres on child development. This is a serious omission particularly when put into consideration the fact that there is an increase in the number of children being taken to these centres and therefore an urgent need for investigation of the effect of the centres on child development. In view of this, the study sought to find out whether the centres are achieving the set objectives and their effect on the child.

\section{Methodology}

This study was based on Piaget's cognitive development theory (1969) in an attempt to explain the factors affecting the establishment of early childhood development centres in Kakamega municipality. It focused on teachers, proprietors, DICECE officers, Faith Based Organizations and parents of ECD Centres in Kakamega Municipality. This study was based on a descriptive survey research design. Simple random sampling was used to select the respondents for the study. The sample was drawn from a population of 50 ECD centres located in Kakamega municipality. A sample of 130 respondents which represented $29.5 \%$ of the total population of 440 was selected using simple random sampling. From the population of 50 ECD centres, a sample of 14 ECD centres were stratified into two sub-groups that is; 7 private and7 public ECD centres whereby, 7 proprietors from private ECD centres and 7 members of the school management committee from public ECD centres were selected. Using purposive sampling technique: 8 Faith based organizations and 3 DICECE officers were selected.

Data for the study was collected through questionnaires, interviews and participatory observation. The questionnaire was prepared into 2 categories which covered proprietors and teachers of ECD centres. The questionnaires contained both open and closed-ended questions with items to which an individual was required to choose from the provided alternatives or give his or her opinion for open ended items. Interview schedules for the parents, DICECE officers and religious leaders were also used. The researcher also gathered information by observing the teaching learning materials, type of infrastructure, furniture and equipment available for children in ECD centres and enrolment records. The observation helped to verify the responses through questionnaires and interview schedules.

To ensure content validity of the research instruments, they were presented to three experts from the departments of Educational Psychology and Curriculum Instruction of Masinde Muliro University for examination and verification. To test whether research instruments were reliable the test re-test method was employed to establish the reliability of the questionnaire. The questionnaires were administered to 3 teachers and 3 proprietors in the pilot study within an interval of two weeks. Two centres which did not constitute the final sample were selected. From the two sets of scores, computation for correlation coefficient was calculated using the Pearson product moment correlation coefficient. The $(r)$ values obtained were 0.73 and 0.76 respectively which were considered to be high enough to enable the questionnaire to be considered reliable in gathering the required data. 0.5 is the minimum reliability coefficient value required to judge an instrument as reliable (Koul, 1984). Hence the questionnaires were accepted as reliable for the study. Data was analyzed using descriptive statistics such as frequency counts, means and percentages. 
DEVELOPMENT

Vol. 1, No. 4, 2012, E-ISSN: $2226-6348$ C 2012 HRMARS

\section{Results and Discussion}

The interviews conducted with the DICECE officers, revealed that establishment of ECD centres is encouraged by; accessibility of children, parents' affordability to pay school dues, busy schedules, enlightenment on the need for children to attend ECDE, and encouragement by the government. This concurs with the report by Chaube and Chaube (2003) that in the United States of America, the development of pre-primary education is a result of the vocational tendency and busy life of people there. Parents are unable to keep their children with them during their hours of work. Hence there was need for such schools which might give young children protection and an educational environment. Thus, ECD centres have been established due to busy schedules of parents. These findings also agree with the World Bank report of 1997 which noted that the government of Kenya got involved in the provision of early childhood education in the 1970 ' 2 by providing training support and supervision for the centres that had already been established by the communities.

It further agrees with the ministry of education and Bernard Van Leer Foundation observation that children in pre-schools are provided with adequate physical safety and social security especially during the time of the day when parents are at work and there is no one at home to provide care to them. Pre-schools thus save working mothers from the continual nightmare of worrying that their children are not provided with a warm, intimate and continuous relationship when they are involved in viable economic activities outside their homes. A report by Republic of Kenya (2006) also observed that the government has encouraged the policy of partnership in the provision of services for infants and children. This has facilitated the participation of numerous partners who provide diverse services and programs for children that would otherwise have been available. It is therefore clear that establishment of ECD centres is enhanced by the government.

The interviews further revealed that, the DICECE officers concur that according to the MoE policy the age between two and a half and three years is the right age for children to join ECD. Parents were also asked to give their opinion on the age of children taken to ECD centres. Their responses are given in table 1.

Table 1: Parents' Opinion on Age of Children Taken to ECDC

\begin{tabular}{lllll}
\hline Age & Public & Private & Frequency & Percentage \\
Below 3 yrs & 5 & 4 & 9 & 42.8 \\
$3-4$ & 3 & 5 & 8 & 38.1 \\
$4-5$ & 1 & 2 & 3 & 14.3 \\
Above 5 & 1 & 0 & 1 & 4.7 \\
Total & $\mathbf{1 0}$ & $\mathbf{1 1}$ & $\mathbf{2 1}$ & $\mathbf{1 0 0}$ \\
\hline
\end{tabular}

The responses from the interviewed parents revealed that $42.8 \%$ of the parents agree on an age below three years for children to be taken to ECD while $38.1 \%$ recommend three to four years, $14.3 \%$ four to five years and only $4.7 \%$ agree on above five years. This is in agreement with the MOEST report of 2003 which noted that the age group for ECD is defined as $0+-5+$ in official documents such as the Education Sector Strategic plan and national Action plan on Education for all. 
The parents were further interviewed to choose reasons as to why they take their children to ECD centres. Table 2 shows their responses.

Table 2: Reasons for taking children to ECDC

\begin{tabular}{lllll}
\hline Reasons & Public & Private & Frequency & Percentage \\
Lack of house help & 2 & 2 & 4 & 28.6 \\
Other commitments & 4 & 2 & 6 & 42.8 \\
To have freedom & 0 & 0 & 0 & 0 \\
Avoid disturbance & 1 & 3 & 4 & 28.6 \\
Total & $\mathbf{7}$ & $\mathbf{7}$ & $\mathbf{1 4}$ & $\mathbf{1 0 0}$ \\
\hline
\end{tabular}

Findings from table 2 indicate that $42.8 \%$ of the parents agreed that other commitments (e.g. job) were the main reasons for taking their children to ECD, $57.2 \%$ agreed on lack of house help and avoiding disturbance as main reasons. However, there were parents who felt there were other reasons for taking children to ECD, these include; to learn and to give the child a strong academic background. This suggests that most parents take their children to ECD centres at an early age to be taken care of due to busy schedules and to be given a strong academic background. This corroborates the report of the National Committee on Education Objectives and Policies (1976) which emphasized that the preparation of a child's foundation for primary education and social development could make all the difference to the child's future. It further concurs with the report by the World Bank that early childhood education has been promoted as away to improve early learning experiences of poor children and as a means of improving America's education system in order to compete successfully with other countries (World Bank, 1997). The report further adds that the changing role of women and such social trends as dual-income families, divorce and single parenthood have accelerated this trend. Therefore it can be concluded that ECD centres are established to offer protection and care for children whose parents are unable to keep at home due to busy schedules. The centres therefore act as homes for these children. Shiundu and Omulando (1992), also observed that education as a comprehensive exposure to opportunities and challenges in life aimed at achieving an all-round preparation of the individual for the challenges and roles awaiting him/her as a member of his/her immediate society. It is a conscious effort by some social institution in the system of education to promote certain approved ideals and values of the community. Therefore, education at an early age is important as a means of preparing one for responsibilities and challenges in later life. 
DEVELOPMENT

Vol. 1 , No. 4, 2012, E-ISSN: $2226-6348$ @ 2012 HRMARS

In response to the question on the motive for establishing ECD centres, responses from respondents were as presented in figure 1

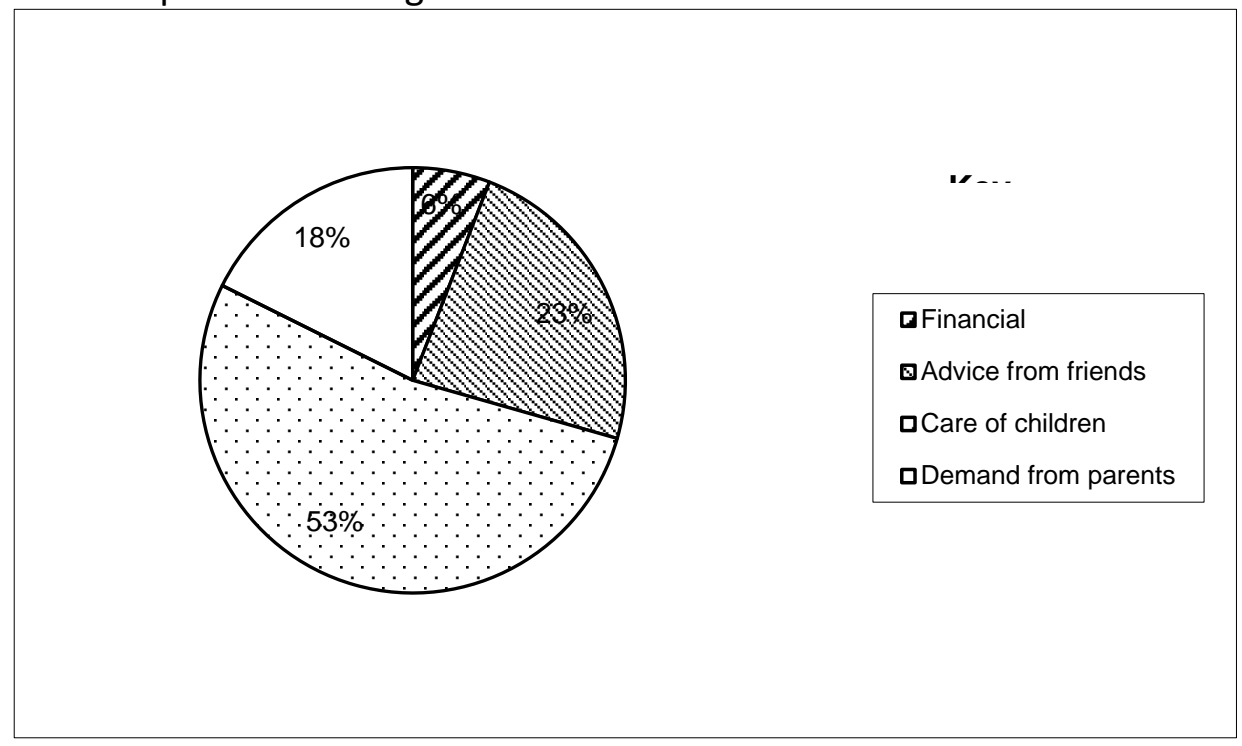

Figure 1: Proprietors motive of establishing ECDEC

Basing on the results from figure 1, a majority of the proprietors (53\%) found care for children as the only strong reason for setting up the ECD centres while $18 \%$ were pressured by parents, $23 \%$ were advised by friends while a mere $6 \%$ were set up for financial reasons. This implies that ECD centres are basically meant to care for children; however, some have been established for financial benefits. This concurs with the observations by Sifuna and Karugu (1988) who pointed out that in some districts, nursery schools were started as nutrition centers where children could sing, listen to stories and play organized games whole milk or soup was prepared. In this case, the major aim of establishing these pre-schools was to provide custodial care that would bring children closer to the necessary social services.

\section{Conclusions}

Based on the findings of the study, it was concluded that: establishment of ECD centres is encouraged by; accessibility of children, parents' affordability to pay school dues, parents' busy schedules, enlightenment on the need for children to attend ECDE, pressure from parents and encouragement by the government.

The study therefore recommends that: the government should, through the ministry of education ensure that ECDE centres are established according to the government policy to ensure proper care of the children. The government should also come up with a specific policy on the appropriate facilities required in ECD centres and ensure its implementation. Research should be conducted on various areas of early childhood development and findings of such research should be used to improve the operations of the section.

\section{References}

Eshiwani, S. G. (1993). Education in Kenya since independence. Nairobi: East African Publishers

Gachathi, P. J. (1976). Report of the National Committee on Educational Objectives and Policies, Ministry of Education. Nairobi: Government Printer 
Kabiru, M. (1997). The status of Early Childhood Education in Kenya. Nairobi: NACECE Kenya Institute of Education. (1999). Guidelines for Early Childhood Development in Kenya, $\left(2^{\text {nd }}\right.$ ed). Nairobi: KIE.

(1992). Early childhood Care and education in Kenya: A report of an Evaluation of UNICEF-Sponsored Districts. Nairobi: KIE NACECE (1987). Early childhood Education in Kenya: Implications Policy and Practice:

(1987). Evaluation of NACECE-DICECE programme. Nairobi: Kenya

Kerlinger, N. F. (2004). Foundations of Behavioral research ( $2^{\text {nd }}$ ed.). Delhi: Subject Publications

Ministry of Education and Benard Van Leer Foundation (1993). Report of the National Seminars on Pre-school Education and its development in Kenya. Malindi: 18-19 June, 1982. Nairobi: Afropress Ltd.

Ministry of Education Science and Technology. (2001). Education for All (EFA) in Kenya: A national Handbook for 2000 and beyond. Nairobi: UNESCO

Ministry of Education Science and Technology. (2003). Background Report of Kenya for the UNESCO/OECD Early Childhood Policy Review Project. Nairobi: Government of Kenya.

Piaget, J., \& Inhelder, B. (1969). The Psychology of the Child. New York: Basic Books.

Psacharapoulos, G., \& Woodhall, M. (1985). Education for Development: An Analysis of Investment choices. London: Oxford University Press

Republic of Kenya. (2006). National Early Childhood Development policy Framework. Nairobi: Government Printer

(1964). Education Structure in Kenya. Nairobi: Jomo Kenyatta Foundation

(1971). Commission of Enquiry. Nairobi: Government Printer

(1972). Development Plan 1989 - 1993. Nairobi: Government Printer

(Bessey Report)

(1976). Report of the National committee on Educational Objectives and

Policies.(Gachathi Report) Nairobi: Government Printer

(1988). Presidential Working party on education and manpower training for the next decade and beyond. Nairobi: Government Printer

(1984): 8-4-4 System of Education_Nairobi: Government Printer

Shiundu, J. O., \& Omulando, S. J. (1992). Curriculum: Theory and Practice in Kenya. Nairobi: Oxford University Press

Sifuna, D. N., \& Karugu, A. M. (1988). Contemporary Issues in Education. Nairobi: Kenyatta University.

Thompson, R. A. (1987). Education and Development in Africa. London: Macmillan Publishers Ltd.

Wilson, J. (2000). Key Issues in Education and Teaching. New York: British Library cataloguing publication Data 